\title{
NITROGEN FERTILIZATION IN WET AND DRY
}

\section{CLIMATE}

\author{
Laureti $^{1^{*}}$, D., Pieri ${ }^{1}$, S., Vannozzi ${ }^{2}$, G.P., Turi $^{2}$, M. and Giovanardi ${ }^{2}$, R. \\ ${ }^{1}$ CRA Istituto sperimentale per le colture industriali Osimo (AN) Italy, via Cagiata, \\ 90 - 60027 Osimo (AN). \\ ${ }^{2}$ Dipartimento di Scienze Agrarie e Ambientali Università degli Studi di Udine, \\ Via delle Scienze, 208 - 33100 Udine
}

Received: October 10, 2006

Accepted: May 15, 2007

\section{SUMMARY}

Fertilization may help crops to yield better. To determine whether meteorological and soil conditions influence the productive response of nitrogen fertilization in sunflower, a study was conducted in an Italian interregional project (BIOLI). The effects of nitrogen fertilization on two commercial higholeic varieties (Carnia and PR 64 H 61) was investigated in North East (Udine) and East Central Italy (Osimo) during 2005. Nitrogen fertilization was not effective in Osimo under rainfed and drought conditions, whereas the highest $\mathrm{N}$ level gave the best yield in Udine in wet and irrigated conditions. In both locations plant size was positively influenced by fertilization.

No differences were observed among varieties in Osimo, whereas in Udine the locally selected hybrid had the best performance. Nitrogen fertilization is suggested only in good weather conditions and in nitrogen poor soil. Under drought conditions nitrogen influences plant growth but not yield.

Key words: sunflower, fertilization, nitrogen, seed yield, drought conditions, good water conditions

\section{INTRODUCTION}

As in other crops sunflower requires NPK fertilization. In Italy, trials with potassium $(\mathrm{K})$ and phosphorus $(\mathrm{P})$ in the last decade did not show any response in the crop due to the naturally high level of potassium in the soil, at least $160 \mathrm{mg} / \mathrm{kg}$ of available $\mathrm{K}_{2} \mathrm{O}$ (international method), or due to the large quantity of fertilizer applied, in the effort to build up phosphorus levels. For phosphorus, the levels above $10-20 \mathrm{mg} / \mathrm{kg}$ of $\mathrm{P}_{2} \mathrm{O}_{5}$ in the soil (Olsen method) is maintained by annually applying the amount that was removed by the previous crop. In addition, the sunflower has only moderate phosphorus requirements and it utilizes mycorrhizas (Glass, 1988).

\footnotetext{
* Corresponding author: e-mail: domenico.laureti@entecra.it
} 
Nitrogen fertilization is very variable and it depends on amounts of the element salready present in the soil and potential yield of the environment. Crnobarac et al. (2004) and Monotti (1978) reported that $100 \mathrm{~kg} / \mathrm{ha}$ was suitable, Malligawad et al. (2004) stressed the importance of nitrogen combined with phosphorus and potassium and reported better yield when the ratio of the first two elements was between 1.5 and 2.0 (results of two experiments). Steer et al. (1994) reported that sunflower has a high nitrogen requirement. Bonari et al. (1992) associated the needs for nitrogen with available water. Laureti and Pieri (1999 and 2001) reported that 40$80 \mathrm{~kg} / \mathrm{ha}$ (depending on the available water) of fertilizer alone or associated with green manuring was enough. Moreover, according to Merrien et al. (1986), the soil nitrogen participates with $70 \%$ in the plant nutrition and it is adsorbed particularly from 40 to 80 days after emergence. When flowering starts (60 days after emergence), $50 \%$ of the nitrogen adsorbed is in the leaf. Afterwards the nitrogen moves to the head and finally to the seeds. The coefficient of nitrogen fertilizer utilization in sunflower is $20-30 \%$ (60\% in wheat) and that coming from fertilizers is adsorbed starting from flowering.

In an effort to contribute to the debate, three levels of nitrogen were tested in an interregional project.

\section{MATERIALS AND METHODS}

To study the nitrogen response of two high-oleic sunflower hybrids (Carnia and PR $64 \mathrm{H} \mathrm{61})$, three different levels of $\mathrm{N}(0 ; 60 ; 100 \mathrm{~kg} / \mathrm{ha})$ were used in two field experiments in two locations during 2005, one under rainfed conditions at Osimo, East Central Italy, and the other under irrigated conditions at Udine, North East Italy. The experiments were laid in a randomized complete block design with four replicates with an individual plot size of $279 \mathrm{~m}^{2}(9 \times 31 \mathrm{~m})$.

Weather conditions (temperature and rainfall) observed during the experiments are presented in Figure 1.

The average annual rainfall at Osimo is usually half that at Udine. In the experimental year the rainfall at Osimo was normal whereas, in May and June, the levels were below normal in Udine and it was necessary to compensate for moisture shortage with four irrigations of $30 \mathrm{~mm}$ each, every ten days starting from the $10^{\text {th }}$ of May until the $10^{\text {th }}$ June (May 10 and 20; June 1 and 10).

Soil tests showed high phosphorus and potash levels in both locations but low nitrogen content, especially in Udine (Table 1).

The soil was a Vertisol in Osimo with good water availability down to a deep level, whereas the soil was gravely at Udine with good water availability only in the upper $50 \mathrm{~cm}$ and than very poor water availability at deeper level. To satisfy crop 
water requirements four irrigations (30 $\mathrm{mm}$ each) were done in May and June in Udine.
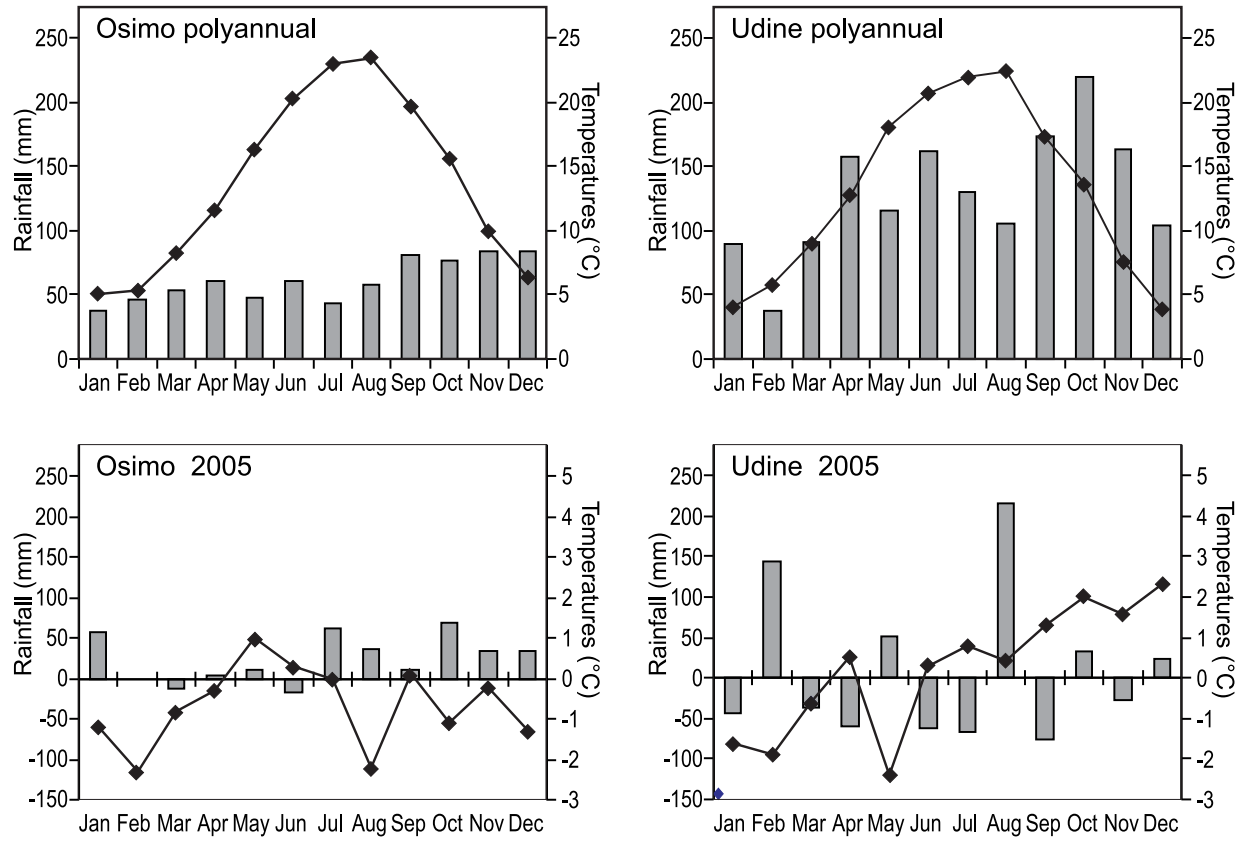

Figure 1: Differences of rainfall $(\mathrm{mm})$ (columns) and mean temperatures $\left({ }^{\circ} \mathrm{C}\right)$ (lines) in 2005 with the previous polyannual period of 20 years for Osimo and 10 years for Udine.

Table 1: Chemical properties of experimental field soil

\begin{tabular}{lccc}
\hline & & Osimo & Udine \\
\hline sand & $\mathrm{g} / \mathrm{kg}$ & 133 & 400 \\
silt & $\mathrm{g} / \mathrm{kg}$ & 472 & 430 \\
clay & $\mathrm{g} / \mathrm{kg}$ & 395 & 170 \\
nitrogen $(\mathrm{N})$ & $\mathrm{g} / \mathrm{kg}$ & 1.1 & 0.2 \\
phosphorus $(\mathrm{P})$ & $\mathrm{mg} / \mathrm{kg}$ & 11 & 41 \\
potash $(\mathrm{K})$ & $\mathrm{mg} / \mathrm{kg}$ & 423 & 200 \\
\hline
\end{tabular}

\section{RESULTS AND DISCUSSION}

Sunflower yield in Italy is greatly dependent on the amount of water stored in the soil and on the amount and distribution of rainfall during the growing season. In the summer of 2005, the rainfall at Osimo, before blooming and seed filling, was below average so the yield was less than expected based on plant size. In fact, during the whole cycle, the better fertilized plots were always greener, taller and with larger leaves (Table 2). 
The only data recorded for this aspect, plant height, was in fact influenced by nitrogen. The plants were taller with higher doses of nitrogen at both Osimo and Udine.

Table 2: Sunflower response to nitrogen fertilization

\begin{tabular}{lcccccccccc}
\hline \multirow{2}{*}{$\begin{array}{l}\text { Nitrogen } \\
\text { kg/ha }\end{array}$} & \multicolumn{2}{c}{ Yield t/ha } & \multicolumn{3}{c}{ Oil content \% } & \multicolumn{3}{c}{ Oil yield t/ha } & \multicolumn{3}{c}{ 1000-seed weight g Plant height } \\
\cline { 2 - 10 } & Osimo & Udine & Carnia & PR64H61 & Osimo & Udine & Osimo & Udine & cm \\
\hline 0 & 2.14 & 2.27 & 47.4 & 48.1 & 0.91 & 1.01 & 62.3 & 48.2 & 165 \\
60 & 2.24 & 2.27 & 49.0 & 47.8 & 0.96 & 1.02 & 62.8 & 47.6 & 173 \\
100 & 2.24 & 3.28 & 45.8 & 47.9 & 0.94 & 1.42 & 62.6 & 55.6 & 178 \\
\hline LSD & \multicolumn{2}{c}{0.31} & \multicolumn{2}{c}{1.3} & \multicolumn{2}{c}{0.14} & 4.07 & 4 \\
\hline
\end{tabular}

The data recorded agree with those of Blanchet et al. (1987) who found a low response whenever water availability was less than $200 \mathrm{~mm}$ during the crop cycle. In Udine, on the contrary, the highest nitrogen dose gave the best yield while the intermediate dose $(60 \mathrm{~kg} / \mathrm{ha})$ did not differ from the control (Table 1).

The highest yield was due to improved seed weight and number of seeds per plant. The positive response to nitrogen in Udine could be related to the very low nitrogen level in the soil. The improvement in Osimo was not evident because seed set was negatively influenced by the scarcity of rainfall during blooming; the subsequent good meteorological conditions of above-average rainfall only allowed an increased seed size.

The seed oil content changed in function of fertilization only in Carnia (Table 2), which decreased the oil value at the highest nitrogen rate, but not in PR $64 \mathrm{H} 61$. Oil yield showed the same figures as seed yield, with a higher value only for the highest nitrogen fertilization level in Udine.

In spite of good water availability, the crop in Udine did not reach the same 1000-seed weight (TSW) due to a large number of seeds set.

Yield differences were not observed in the hybrids used in the experiment at Osimo (Table 2), whereas at Udine the locally selected hybrid (Carnia) was significantly more productive than PR $64 \mathrm{H} 61$ probably due to a higher capacity for set seed. Carnia also had the best oil content at Udine and consequently the best oil yield, whereas at Osimo differences were not found.

Table 3: Differences among the varieties

\begin{tabular}{|c|c|c|c|c|c|c|c|c|c|c|}
\hline \multirow{2}{*}{ Variety } & \multicolumn{2}{|c|}{$\begin{array}{l}\text { Yield } \\
\text { t/ha }\end{array}$} & \multicolumn{2}{|c|}{$\begin{array}{c}\text { Oil content } \\
\%\end{array}$} & \multicolumn{2}{|c|}{$\begin{array}{l}\text { Oil yield } \\
\text { t/ha }\end{array}$} & \multicolumn{2}{|c|}{$\begin{array}{l}\text { 1000-seed } \\
\text { weight g }\end{array}$} & \multicolumn{2}{|c|}{$\begin{array}{c}\text { Plant height } \\
\mathrm{cm}\end{array}$} \\
\hline & Osimo & Udine & Osimo & Udine & Osimo & Udine & Osimo & Udine & Osimo & Udine \\
\hline CARNIA & 2.39 & 2.81 & 45.2 & 49.6 & 0.89 & 1.27 & 60.4 & 47.7 & 153 & 185 \\
\hline PR64H61 & 2.24 & 2.17 & 48.3 & 47.5 & 0.99 & 1.07 & 64.7 & 53.2 & 177 & 175 \\
\hline LSD & \multicolumn{2}{|c|}{0.25} & \multicolumn{2}{|c|}{1.1} & \multicolumn{2}{|c|}{0.11} & \multicolumn{2}{|c|}{4.07} & \multicolumn{2}{|c|}{5.0} \\
\hline
\end{tabular}

Regarding plant height, PR64H61 was influenced little by water availability, whereas Carnia was more sensitive. 


\section{CONCLUSIONS}

According to the literature, the response of sunflower to nitrogen fertilization is influenced by weather conditions during the season and the natural nitrogen level in the soil.

Under drought conditions and medium natural soil nitrogen content, the response of the crop was evident in the size of the plant but not in its yield. Conversely, excessive growth could cause a lower water use efficiency, but this was not evident in the trials.

Under good water conditions and low nitrogen content in the soil, sunflower responded positively to fertilization. The highest dose improved the amount of seeds set, seed size, and consequently, the yield.

The results for the varieties tested were similar in Osimo and significantly different in Udine where the local variety was shown to be most productive.

\section{REFERENCES}

Blanchet, R., Thomas, G. and Gelfi, N., 1987. Influence de l'alimentation azoté sur le nombre d'akénes et le rendement du tounasol (Helianthus annuus L., cv. Pharaon) dans differentes situations hydriques. Agric. Mediterranea, 117:111-123

Bonari, E., Vannozzi, G.P., Benvenuti, A., and Baldini, M., 1992. Modern aspects of sunflower cultivation techniques. Proceedings $13^{\text {th }}$ International Sunflower Conference, Pisa 7-11 September, 3-51

Crnobarac, J.Z., Poljak, N.M., Dušanić, N.Z., and Marinković, B.J., 2004. Proceedings $16^{\text {th }}$ International Sunflower Conference, Fargo, ND USA. 1:371-376.

Glass, K., 1988. Sunflower: Fertilizer for high yield and quality. Int. Potash Inst. Bull. 10:1-38. Laureti, D. and Pieri, S., 1999. Fertilizzazione biologica del girasole. L'Informatore Agrario LV (10), supplemento, pp. 23-25.

Laureti, D. and Pieri S., 2001. Sovescio di leguminose nella fertilizzazione del girasole L'Informatore Agrario, LVII, 30:52-54.

Malligawad, L.H., Parameshwarappa, K.G. and Giriraj, K., 2004. Studies on the effect of ratios and level of NPK fertilizer nutrients of the productivity of hybrid sunflower under rainfed farming situations. Proceedings $16^{\text {th }}$ International Sunflower Conference, Fargo, ND USA. 1:377-386.

Merrien, A., Arjaure, G. and Maisonneuve, C., 1986. Besoins en elements minéraux chez le Tournesol dans les conditions francaises. Info. Techn. CETIOM 95.II:8-19

Monotti, M., 1978. Il girasole: problemi, tecnica colturale, risultati delle prove di confronto tra varietà. L'Inf. Agr. 16:1713-1429.

Steer, B.T., Hocking P.J., Kortt, A.M and Roxburg, C.M., 1994. Nitrogen nutrition of sunflower (Helianthus annuus L.): Yield components, the timing of their establishment and seed characteristics in response to nitrogen supply. Field Crops Res. 9:219-236.

\section{FERTILIZACIÓN CON NITRÓGENO EN EL CLIMA SECO Y HÚMEDO}

\section{RESUMEN}

La fertilización ayuda a las plantaciones a dar más alto rendimiento. Para determinar si las condiciones meteorológicas y del terreno influyen en la reacción de producción de girasol en fertilización con nitrógeno, se han realizado investigaciones dentro de un proyecto interregional (BIOLI) organizado en Ita- 
lia. La influencia de fertilización por nitrógeno en dos variedades alto oleicas comerciales (Carnia y PR 64 H 61) fue investigado en Italia septentrional-oriental (Udine) e Italia central-oriental (Osimo) a lo largo del año 2005. La fertilización con nitrógeno no tuvo efecto en Osimo ni en las condiciones húmedas ni en las condiciones secas, mientras que la más alta dosis de $\mathrm{N}$ dio el rendimiento más alto en Udine y en las condiciones húmedas y en irrigación. En ambas localidades, la altura de la planta reaccionó positivamente en fertilización.

No hubo diferencias obvias entre las variedades en Osimo, mientras que en Udine, el híbrido localmente seleccionado mostró los mejores resultados. La fertilización con nitrógeno se recomienda sólo para las condiciones de tiempo oportunas y para los terrenos con bajo contenido de nitrógeno. En las condiciones de sequía, el nitrógeno influye en el crecimiento de la planta, pero no en su rendimiento.

\section{FUMAGE PAR L'AZOTE DANS UN CLIMAT SEC OU HUMIDE}

\section{RÉSUMÉ}

Le fumage aide les cultures à fournir un meilleur rendement. Des observations ont été faites dans le cadre d'un projet interrégional (BIOLI) en Italie pour déterminer si les conditions météorologiques et les conditions du sol avaient un effet sur la réaction productrice du fumage par l'azote chez le tournesol. L'effet du fumage par l'azote sur deux sortes commerciales à haute teneur oléique (Carnia et PR $64 \mathrm{H} \mathrm{61}$ ) a été examiné au nord-est (Udine) et au centre est de l'Italie (Osimo) au cours de l'année 2005. Le fumage par l'azote n'a eu d'effet à Osimo ni dans des conditions d'humidité ni dans des conditions de sécheresse tandis que la plus grande dose d'azote a donné un plus grand rendement en Udine, dans des conditions d'humidité et d'irrigation. Dans les deux localités, la hauteur de la plante a réagi positivement au fumage.

Il n’y a pas eu de différences évidentes parmi les sortes à Osimo tandis qu'à Udine l'hybride sélectionné localement a montré les meilleurs résultats. Le fumage par l'azote est recommandé seulement dans des conditions météorologiques favorables et pour un sol pauvre en azote. Dans les conditions de sécheresse, l'azote a un effet sur la croissance de la plante mais non sur son rendement. 